IJIET, e-ISSN 2548-8430, p-ISSN 2548-8422, Vol. 2, No. 2, July 2018

\title{
IJIET
}

International Journal of Indonesian Education and Teaching

http://e-journal.usd.ac.id/index.php/IJIET

Sanata Dharma University, Yogyakarta, Indonesia

\section{BASIC TENSE PROBLEMS OF THE FIRST SEMESTER STUDENTS OF ENGLISH LANGUAGE EDUCATION STUDY PROGRAM}

\author{
Elisabeth Wulan Wahyuningtyas and Barli Bram \\ Sanata Dharma University \\ elisabeth.wulan03@gmail.com and barli@usd.ac.id \\ https://doi.org/10.24071/ijiet.v2i2.1509 \\ received 14 December 2017; revised 2 May 2018; accepted 29 June 2018
}

\begin{abstract}
This paper investigated the problems of understanding basic or fundamental tenses in English grammar (the present tense, present continuous tense, present future tense, and present future continuous) that are faced by the first semester students of the English Language Education Study Program of Sanata Dharma University, Yogyakarta. Basic tenses in English grammar play a decisive role in various aspects related to learning English as the target language. Accordingly, itis essential to conduct a study on the issues of basic tenses in order to assist students to overcome their grammatical problems. Data were collected through questionnaires that were emailed to the participants. Results showed that the students had difficulties in producing or analyzing the present continuous tense, the present perfect tense and the present perfect continuous tense. The first semester students also faced difficulty in remembering the formula of each tense. The students admitted that they rarely reviewed the basic tenses regularly and theyfound it difficult to comprehend their grammar lessons well in the classroom.
\end{abstract}

Keyword: basic tense, English grammar, English learner, present tense

\section{Introduction}

In Indonesia, English is taught as a first foreign language (Lauder, 2008) and it is included in the Indonesian curriculum which states that the students should have English lessons in their school. Therefore, learning English in Indonesia is an obligation for the students in all levels, namely the Elementary School, Junior High School, and Senior High School (Lie, 2007). It might because that English is global language (Lauder, 2008) that is used by many people around the world to be able to communicate each other so that Indonesia Government of education include English as one of the compulsory subjects to be taught at schools. Moreover, there are many Indonesia universities that provide English as one of the study program within in both English department and non English department. Lie (2007, see Bram, 2016, p.58) said that the university students who do not take English-based study program, like the English Education or English Arts Study Program are given an English course "two hours per week" to improve their English skills, especially in speaking for good communication in English. It is to prepare the universities students to have good skills to communication in English 
because nowadays, "English competence" is needed to get a good job and position in the workplace (Siregar, 2010).

Furthermore, in learning English, it is also an obligation for the students to learn also grammar or structure of English. It is because grammar is the fundamental in comprehending sentences in English. However, the students might face difficulties in learning and understanding English grammar because the students cannot keep away from their first language (see Sunarto, 2012, p. 187; Çakır, 2011) whereas, the patterns in English sentences are definitely different from sentences in Indonesian (Inayati \& Damayanti, 2016). In this study, the writer will investigate the students' difficulties and what method(s) they suggest to get meaningful learning activities in learning English grammar.

English grammar is difficult to master, especially for students who learn English as a foreign language and the students may face difficulties in applying English grammar in both speaking and writing in English (Elturki, 2014). However, many students assumed that English grammar is an uninteresting courseto learn by a using handbook (Vannestal \& Linquist, 2007). It is still hard to motivate the students to learn English grammar even though there are manyimprovements in creating English grammar modules which it consists of activitiesfor the students to have "peer discussion" and ability to solve problems in order to improve their knowledge of English grammar (Vannestal \& Linquist, 2007; see Mestari, \& Malabar, 2016, p. 125).

Learning English grammar is regarded as a way to increase the students' English skills and abilities to use it in a suitable and correct way (see Bram, 2014, p. 295 \& Kurniasari, 2017). Indeed, the students will be easier to communicate in good English if they master English grammar. It cannot be denied that the students need to have good, accurate and meaningful English grammar to be able to have good communication in both spoken and written (Mestari, 2016). Furthermore, learning English grammar is also to prepare the students to have ability in reading English text in university level, especially for those who take theEnglish Language Study Program where all of the texts given are in English (Lie, 2007).

Hence, the English grammar teachers should have meaningful plan in teaching. The English grammar learning activities should be interesting and enjoyable so that the students will be encouraged to explore their "innovation and creativity" in creating meaningful way of learning English grammar (Buditama, 2017). Therefore, it is needed for the teachers to provide authentic materials in theteaching learning activities because it is useful and helpful for the students to connect their own learning experiences to the language used by the native speaker of English (Burgess \& Etherington, 2002; Mestari, 2016). By those authentic materials given the teachers, the students will be able to recognize and understand the English grammar in the "real language use" (Mestari \& Malabar, 2016). Moreover, studentcentered is one of effective approaches in understanding basic English grammar (Buditama, 2017). Giving many exercises for the students is needed in order to lead the students to have good memory and understanding on English grammar patterns (Burgess \& Etherington, 2002; Mestari, 2016). As we know, teaching English grammar is "to give some rules" in English and its 
"exceptions" (Çakır, 2011). However, drilling in teaching English grammar is effective so far in order to improve students' grammatical problems in using correct verb within the sentences and differentiating the time in each tense (Nawaz, et al., 2015). Moreover, it also can increase the students writing skills in English. However, the teachers should provide teaching learning activities which are appropriate for both the students' needs and level and also the aims of the course (Mestari \& Malabar, 2016).

\section{Method}

This study was qualitative research, aiming to collect the data as much and detailed as they can (Sandelowski, 2000). Moreover, Ary, Jacobs, Sorensen, and Walker (2013, pp. 25-27) said that in qualitative research, the current writers presented narrative description and interpretation as the results of data analysis in rich and comprehensive detail. Furthermore, this study was a questionnaire-based study. The writers distributed the questionnaire to the participants via email because this channel was considered effective and efficient. The writers then emailed the questionnaire to the participants and asked the participants to send back the complete version which had been filled by them to the writer.

There were 27 participants of this study and they were chosen randomly. All of them were the first semester students in the English Language Education Study Program, Sanata Dharma University (SDU) Yogyakarta, Indonesia. Nonetheless, the writers believed that the number of the participants sufficed since their responses were considered as the representation of the students' problem and suggestion in learning basic tenses of English Grammar. Furthermore, the participants who were involved in this study were those who had ever learned basic English grammar in both Senior High School and university in the beginning semester. Then, to interact with them in order to get information forthis study, the writer contacted them via email because it was an efficient way as what was explained in the previous subsection.

The writers used questionnaires to gain the data. In the questionnaires, the writers created two parts of the questions. The first part was to estimate the students' understanding in analyzing basic tenses of English grammar withinsome sentences and the degree of difficulty for each sentence based on their understanding. Then, the writer put a table to make it easy for the participants to answer the questions (analyzing the sentences). In the table, the writer provided some sentences to be analyzed by the students, alphabets $[\mathrm{A}=$ Present Tense $(\mathrm{PT}), \mathrm{B}=$ Present Perfect Tense (PPT), $\mathrm{C}=$ Present Continuous Tense $(\mathrm{PCT}), \mathrm{D}=$ Present Perfect Continuous Tense (PPCT)] as the participants' answer based on their understanding and analysis on the provided sentences and numbers $(1=$ very easy, $2=$ easy, $3=$ difficult, 4 = very difficult) as the participants' assumption of the difficulty level of those sentences. The writer also provided the example of how to fill the column of the table as the guidance for the students.

Furthermore, the second part was two open-ended questions which allowed the students to elaborate their problem(s) in learning English and their suggestion(s) for the lecturer in creating suitable method(s) in teaching basic English grammar. According to McDonough and McDonough (1997, p. 176), 
open-ended questions may allow the participants to give the detailed information and their point of view about some issue and it is about statements and asks for degrees of agreement. It means that here, the students were able to extend their opinions freely related to the issue in that questionnaire.

\section{Findings and Discussion}

In this sub section, the writers presented the findings gained from the study undertaken. The first part in the questionnaire was to measure the students' understanding about the four basic tenses of English grammar within several sentences. Here, the students' were asked also to give their perception on the difficulty level in learning basic tenses and elaborated it in the first open-ended question in the second part. Thus, table 4.1 showed the students' perception on difficulty level of basic tenses.

Table 4.1 Students' Perception on Difficulty Level of Learning Basic Tenses

\begin{tabular}{llcccc}
\hline \multirow{2}{*}{ No } & \multirow{2}{*}{ Basic Tenses } & \multicolumn{4}{c}{ Level } \\
\cline { 3 - 5 } & & $\mathbf{1}$ & $\mathbf{2}$ & $\mathbf{3}$ & $\mathbf{4}$ \\
\hline 1 & Present Tense & $44 \%$ & $33 \%$ & $19 \%$ & $4 \%$ \\
2 & Present Continuous Tense & $29.63 \%$ & $37.04 \%$ & $29.63 \%$ & $4 \%$ \\
3 & Present Perfect Tense & $4 \%$ & $15 \%$ & $44 \%$ & $37 \%$ \\
4 & Present Perfect Continuous Tense & $7 \%$ & $4 \%$ & $37 \%$ & $52 \%$ \\
\hline
\end{tabular}

Based on the findings of the first part and the first open-ended question in the questionnaire, it could be summarized that the students in the beginning semester had difficulties in understanding the basic tenses of English grammar. As shown in Table 4.1, there were $44 \%$ of students who stated that Present Tense (PT) was easiest tense to be understood. Then, $37 \%$ of students assumed that the Present Continuous Tense (PCT) was still easy to be understood but sometimes they faced difficulty to make or to analyze the sentence of PCT. However, the students said the two tenses, PT and PCT, had ever been learned in Senior High School (SHS). So, when they got the materials about those two tenses in the beginning semester, they did not face serious problems in learning PT and PCT. Although sometimes, they had confusion in differentiating between the two sentences because some of the students assumed that at a glance, those two tenses looked similar. Meanwhile, $44 \%$ of the students regarded that the Present Perfect Tense (PPT) was difficult but more than fifty percent (52\%) students assumed that the Present Perfect Continuous Tense (PPCT) was the most difficult tense compared with the other three. The students considered that it was very complicated to make sentences by using PPT and PPCT.

Furthermore, the writers had classified the students' difficulties in learning basic tenses of English grammar into several main problems. The first was that the student faced difficulty in remembering the formula of each tense. They admitted that they did not have habit to learn basic tenses of English grammar. Hence, it was easy for them to forget the formula of the tenses so in their learning, they faced difficulty in using those tenses. Then, the second was that the students couldnot accept the lecturer's explanation in the classroom well. They assumed that all 
this time, the lecturer's approach in teaching basic tenses especially was uninteresting and they did not have enough exercises to sharpen their understanding. Moreover, the students stated that it was complicated to decide the verb used in the sentence of PPT and PPCT whether it was a base form (V1), past simple (V2), or part participle (V3). In addition, the students mentioned another problem in applying has been/have been in the sentence of PPCT, when it should be has been and when it should be have been. These two tenses (PPT and PPCT) were the most complicated tenses for them.

However, in the second part of the questionnaire, the students elaborated their suggestions of method to learn basic tenses of English grammar. It was aimed for the lecturers, especially those who teach English grammar in the beginning or first semester. There were three main suggestions from the students. The first was that the students needed to have more exercises in making or analyzing sentences for each tense. Thus, it was needed for the lecturers to give them more exercises. So, they would be able to behave themselves to learn English grammar frequently so that they would remember the formulas of the tenses and later on, they would master English grammar, especially Basic tenses. Additionally, the students needed clearer explanations about the tenses because sometimes, it was difficult todetermine and differentiate the time and verbs in each tense. Hence, the lecturers should have different approaches or methods which were more interesting, like providing games as one of tools to give examples or exercises for the students. Analyzing tenses within songs or stories were also suggested by the students because those were more interesting for them rather than sitting and listening tothe lecturer's explanation in the classroom.

\section{Conclusion}

Indeed, learning basic tenses of English grammar is important because it is one of the fundamentals to have good communication in English. However, in the process, the students may face difficulties in understanding English grammar, especially Basic Tenses which have complicated patterns. Most of students who involved in this study assume that Present Perfect Continuous Tense is the most difficult and complicated tense to be learned. However, for other tenses, the students also mention their difficulties in analyzing and differentiating the time and verb used within the tense. It is a challenge for the English grammar teachers to pay attention in conducting or creating teaching learning activities which are meaningful and effective in learning English grammar. Meanwhile, the students suggest that the teachers should give English grammar materials by using interesting and enjoyable way, like providing games and authentic materials. However, having many exercises is also recommended for the students in order to strengthen their knowledge and understanding on English grammar.

\section{References}

Ary, D., Jacobs, L. C., Sorensen, C., \& Walker, D. A. (2013). Introduction to Research in Education. (9th ed). Wadsworth: Cengage Learning. Retrieved on September 21, 2017 from http://bit.ly/2xj8YyL. 
Bram, B. (2014). Language, linguistics and literature: Meaning aspects. In Kristiyani, C., Bram, B., Iswandari, Y.A., Sumarni, L., \& Pasaribu, T.A. (Eds.), Language and Language Teaching Conference (LLTC) 2014 Proceedings [pp. 289-298]. Yogyakarta: English Language Education Study Program of University Sanata Dharma University.

Bram, B. (2016). Self and peer revisions in students' narrative paragraph writing. In Robertson, P., \& Adamson, J. (Eds), The Asian EFL Journal, TESOL Indonesia International Conference Edition, 7, pp. 57-62.

Buditama, M. (2017). Student-centered learning approach in teaching basic grammar. Journal on English as a Foreign Language, 7(2), 209-226.

Burgess, J. \& Etherington, S. (2002). Focus on grammatical form: Explicit or implicit? System, 30(4), 433-458.

Çakır, I. (2011). Problems in teaching tenses to Turkish learners. Theory and Practice in Language Studies, 1(2), 123-127.

Chandra, D., \& Yulia, M. (2018). Nicki Minaj's comments in American idol season 12: An analysis of women's language features. International Journal of Humanity Studies (IJHS), 1(2), 184-192. Retrieved from http://ejournal.usd.ac.id/index.php/IJHS/article/view/684/805

Elturki, E. (2014). An investigation of grammar problems facing English language learners. Humanizing Language Teaching, 16(2).

Inayati, A. M. \& Damayanti, D. (2016). Improving students' grammar ability (simple past tense) using Johny Grammar word challenge application in junior high school. In Proceeding of the International Conference on Teacher Training and Education, 2(1), 876-881.

Kurniasari, M. D. (2017). Tolerating structural ambiguity in grammar learning. International Journal of Indonesian Education and Teaching, 1(1), 85-94. Retrieved from http://e-journal.usd.ac.id/index.php/IJIET/article/view/330

Lauder, A. (2008). The status and function of English in Indonesia: A review of key factors. Makara Hubs-Asia, 8(3), 9-20.

Lie, A. (2007). Education policy and EFL curriculum in Indonesia: Between the commitment to competence and the quest for higher test scores. TEFLIN Journal, 18(1), 01-15.

McDonough, J \& McDonough, S. (1997). Research methods for English language teachers. London: Arnold.

Mestari, S. A. \& Malabar, F. (2016). The use of authentic materials in teaching grammar for EFL students (teachers' perspective). LLT Journal: A Journal on Language and Language Teaching, 19(2), 125-131. Retrieved from http://ejournal.usd.ac.id/index.php/LLT/article/view/306

Nawaz, S., Umer, A., Tabasum, M., Zaman, M., Batool, A., \& Aslam, S. (2015) Difficulties facing by students of L1 in adopting L2. European Journal of English Language, Linguistics and Literature, 2(2), 1-6.

Sandelowski, M. (2000). Focus on research methods-whatever happened to qualitative description? Research in nursing and health, 23(4), 334-340.

Siregar, F. L. (2010). The language attitudes of students of English Literature and D3 English at Maranatha Christian University toward American English, 
British English, and Englishes in Southeast Asia, and their various contexts of use in Indonesia. Philippines ESL Journal, 2(4), 66-92.

Sunarto, E. (2012). On perspectiving in cognitive grammar and communicative. LLT Journal: A Journal on Language and Language Teaching, 15(1), 186194. Retrieved from http://e-journal.usd.ac.id/index.php/LLT/article/view/317

Vannestal, M. E. \& Lindquist, H. (2007). Learning English with a corpus: Experimenting with concordancing in a university grammar course. ReCALL 19(3), 329-350. 